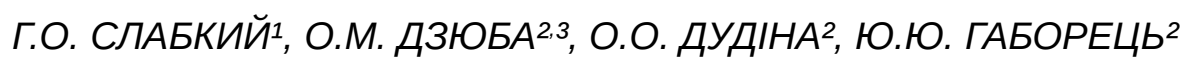

\section{ХАРАКТЕРИСТИКА ІНВАЛІДНОСТІ ДИТЯЧОГО НАСЕЛЕННЯ УКРАЇНИ}

\author{
${ }^{1}$ ДВН3 «Ужгородський національний університет», м. Ужгород, Україна

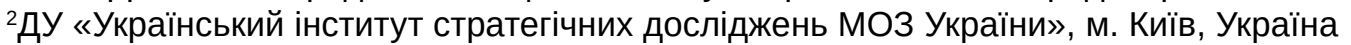 \\ ЗКоледж освіти і терапії імені проф. Казимира Мілановського, м. Познань, Польща
}

\begin{abstract}
Мета: вивчити та проаналізувати показники інвалідності дитячого населення в Україні.
Матеріали і методи. Матеріалами дослідження слугували дані державної статистичної звітності за період 2013-2017 рр. У ході дослідження використано статистичний метод дослідження.

Результати. При зниженні загального показника інвалідності дітей підвищується показник поширеності інвалідності, яка зумовлена ендокринними хворобами, розладами харчування та порушеннями обміну речовин; хворобами шкіри та підшкірної клітковини; розладами психіки та поведінки; хворобами системи кровообігу. У структурі інвалідності у дітей лідирують природжені вади розвитку, десормації та хромосомні аномалії, хвороби нервової системи, розлади психіки і поведінки.
\end{abstract}

Висновки. Високі показники загальної та первинної інвалідності дітей потребують прийняття державної програми їх реабілітації.

КЛЮЧОВІ СЛОВА: діти; інвалідність; загальна; первинна; показники; структура.

Концентрованим відображенням успішності суспільства, соціальної захищеності та рівня і якості здоров'я підростаючого покоління $є$ рівень інвалідності дітей. Він найбільш яскраво ілюструє зниження у дітей ффункціональних можливостей організму, реакцій пристосування і захисту. Питання дитячої інвалідності стають все актуальнішими в умовах стрімкого зростання проблем соціального розвитку, розбалансованості міжособистісних стосунків, тривалих військових дій на сході України і показують необхідність пошуку рішень як медичного, так і соціального характеру, на якісно новому рівні. Дитяча інвалідність $€$ однією 3 найактуальніших проблем не тільки в педіатрії, але й в соціальній програмі суспільства [5].

Відповідно до Міжнародної класифрікації фрункціонування, інвалідності та здоров'я з її додатковим варіантом для дітей та молоді, «інвалідність» $€$ збірним поняттям, що включає порушення, обмеження діяльності та обмеження участі й позначає негативні аспекти взаємодії між конкретною людиною (з певним станом здоров'я) і контекстуальними факторами (довкілля та особистими) цієї людини. Інвалідність не є просто біологічним чи соціальним явищем. За даними ВОО3, інваліди становлять 10 \% населення земної кулі, з них 120 млн - це діти та підлітки, у всьому світі спостерігається тенденція до збільшення кількості дітей-інвалідів [2].

У країнах Центральної та Східної Європи частка дітей-інвалідів становить 2,5\%, 3 них $1 \%$ - це діти 3 тяжкою інвалідністю. Відсоток дітей-інвалідів від загальної кількості дитячого населення в різних країнах складає 2-3-4 \% (США - 4 \%, Велика Британія - 2,5 \%, КНР - 4,9 \%, Україна 2-3 \%). Близько 10-20 \% дітей і підлітків мають обмежені можливості здоров'я, потребують постійного медико-педагогічного супроводу [3, 4].

Значущість проблем інвалідності підтверджується тим, що профілактику неінфекційних хвороб та інвалідності включено до 11 найпріоритетніших медичних заходів, визначених ВООЗ і спрямованих на збереження здоров'я для всіх в Європейському регіоні (ВОО3 «Здоров'я - XXI», «Здоровий початок життя»). Конвенцією ООН про права дитини, яка ратифікована в Україні (ст. 23), передбачено, що кожна дитина, в тому числі й 3 функціональними обмеженнями, «повинна вести повноцінне життя в умовах, які забезпечують гідність, сприяють впевненості в собі і полегшують адекватну участь у житті суспільства». Значущість проблеми інвалідності 3 дитинства також зумовлена тим, що майже у 25 \% інвалідів віком до 50 років інвалідизація зумовлена захворюванням, перенесеним у дитинстві [1].

В Україні закладено конституційні засади допомоги дітям з обмеженнями життєдіяльності. Ратифріковані Законом України Конвенція ООН про права дитини (2009р.) та Конвенція ООН про права інвалідів (2009 р.) [6].

Мета роботи: вивчити та проаналізувати показники інвалідності дитячого населення в Україні. 
Матеріали і методи. Матеріалами дослідження слугували дані державної статистичної звітності за 2013-2017 рр. У ході дослідження використано статистичний метод дослідження.

Результати дослідження та їх обговорення. За даними державної статистики в Україні спостерігається різноспрямована тенденція рівнів інвалідності при, в цілому, тенденції до зниження як поширеності інвалідності у дітей з 210,6 на 10 тис. дітей віком до 18 років у 2013 р. до 208,8 - у 2017 р., так і первинної інвалідності 3 22,9 до 21,6 відповідно (рис. 1).

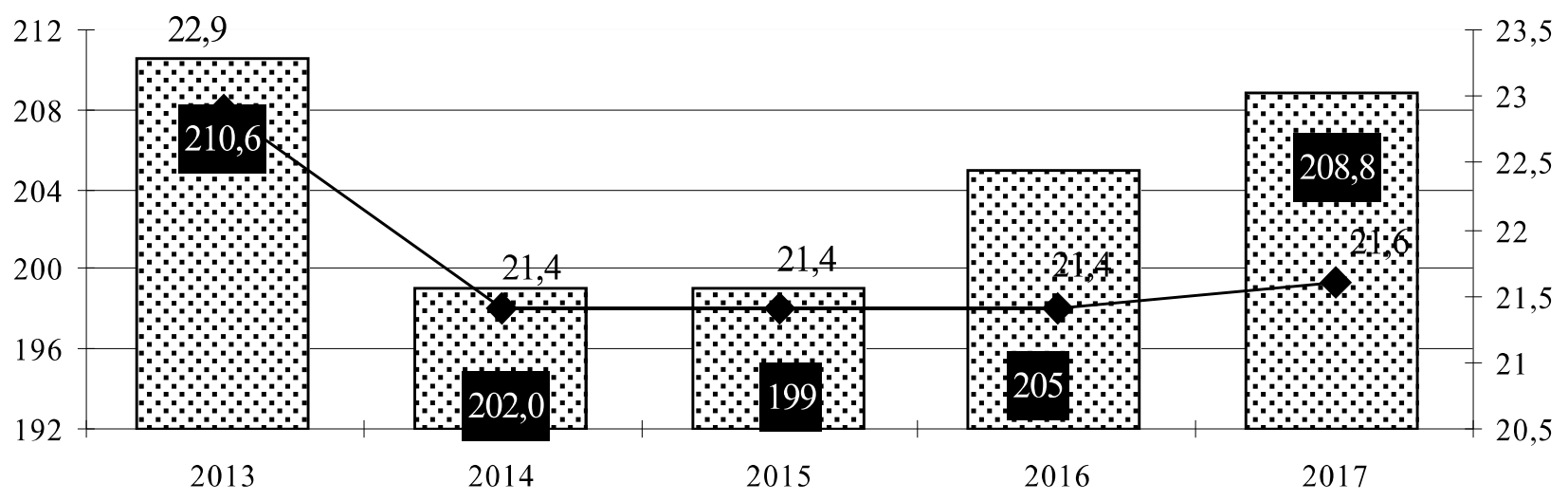

$\because$ Всього — $\multimap$ Встановлено вперше

Puc. 1. Динаміка інвалідності дітей віком до 18 років в Україні у 2013-2017 рр. (на 10 тис. відповідного населення).

Виявлена тенденція дуже тісно пов'язана з початком військових дій на території України, що прямо вплинуло на достовірність статистики та недоліки якості надання медичної допомоги населенню країни, і передусім дітям, які проживають на територіях Донецької і Луганської областей, які завжди мали високі рівні інвалідності, та не входили до статистики даних по АР Крим.

Загальна чисельність дітей-інвалідів упродовж останніх п'яти років зменшилася на 9,2 тис. і у 2017 р. становила 159044 осіб, або 2,08 \% від загальної кількості дітей. За розрахунками Європейської Академії Дитячої Інвалідності, в Україні очікується більше 200 тис. дітей-інвалідів віком до 18 років, з них до 80 тис. з тяжкою інвалідністю, а також близько 1 млн дітей буде вимагати постійного медико-педагогічного супроводу. Порівняння цих даних свідчить про те, що в Україні завищені вимоги щодо встановлення інвалідності. Тенденції збільшення інвалідності дітей притаманні будь-якій цивілізованій державі, бо на перше місце ставиться збереження життя усім дітям. Така постановка проблеми правильна, оскільки дає змогу упорядкувати статистичні дані щодо дитячої інвалідності, збільшити число сімей, охоплених соціальною допомогою, і зумовити точніше планування медичних і медико-соціальних програм щодо створення служб реабілітації та відновного лікування.

У 2017 р., як і в попередні роки, відзначалася диспропорція рівнів загальної інвалідності від 261,3 на 10 тис. дітей віком до 18 років у Чернігівській, 253,4 - у Київській, 248,1 - у Житомирській,
239,6 - у Вінницькій, 239,3 - у Рівненській, 238,0 у Хмельницькій до 176,3 - в Одеській, 195,9 у Херсонській, 202,2 - у Луганській областях. Діапазон регіональних коливань первинної інвалідності дитячого населення України становив від 27,6 на 10 тис. дитячого населення у Вінницькій, 27,2 - у Чернігівській, 26,4 - у Київській до 18,8 у Харківській, 19,6 - в Одеській, 19,7 - у Хмельницькій і 19,8 - у Кіровоградській областях (рис. 2).

Загальновизнано, що рівень інвалідності дітей прямо залежить від поширеності хвороб. Враховуючи однакову тяжкість перебігу захворювань у дітей в різних регіонах, логічно припустити, що розбіжності цього показника по регіонах незначні. Проте проведений нами аналіз засвідчив коливання по регіонах від 9,43 на 1000 захворювань у м. Києві, 10,25-10,98 - у Київській, Івано-Франківській, Харківській і Одеській до 13,03-13,68 - у Полтавській, Херсонській, Хмельницькій, Запорізькій, Миколаївській та Чернівецькій областях (рис. 3).

Отримані дані вказують на доцільність проведення тематичних клінічних аудитів із первинної профрілактики захворюваності дітей та якості медичної допомоги дітям із тяжкими інвалідизуючими хворобами у Запорізькій, Чернівецькій та Миколаївській областях.

Спеціальний аналіз частки інвалідів серед загальної кількості хворих дітей по класах хвороб засвідчив, що найбільш значущими в розвитку інвалідизуючих станів є природжені вади розвитку, деформації та хромосомні аномалії, розлади психіки та поведінки, новоутворення та хвороби нервової системи, хвороби вуха та соскоподібного 


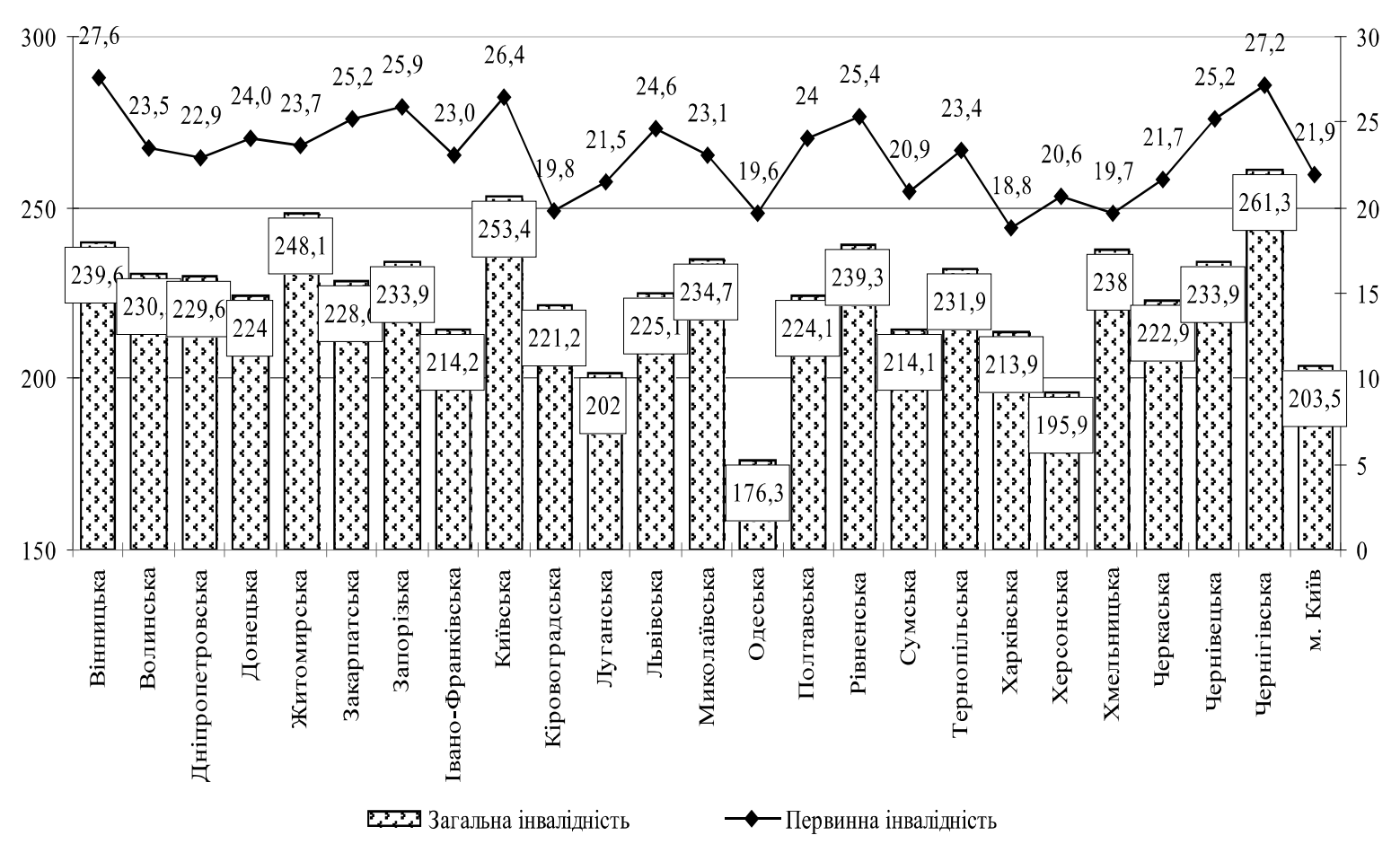

Puc. 2. Характеристика загальної та первинної інвалідності в Україні у 2017 р. (на 10 тис. дитячого населення).

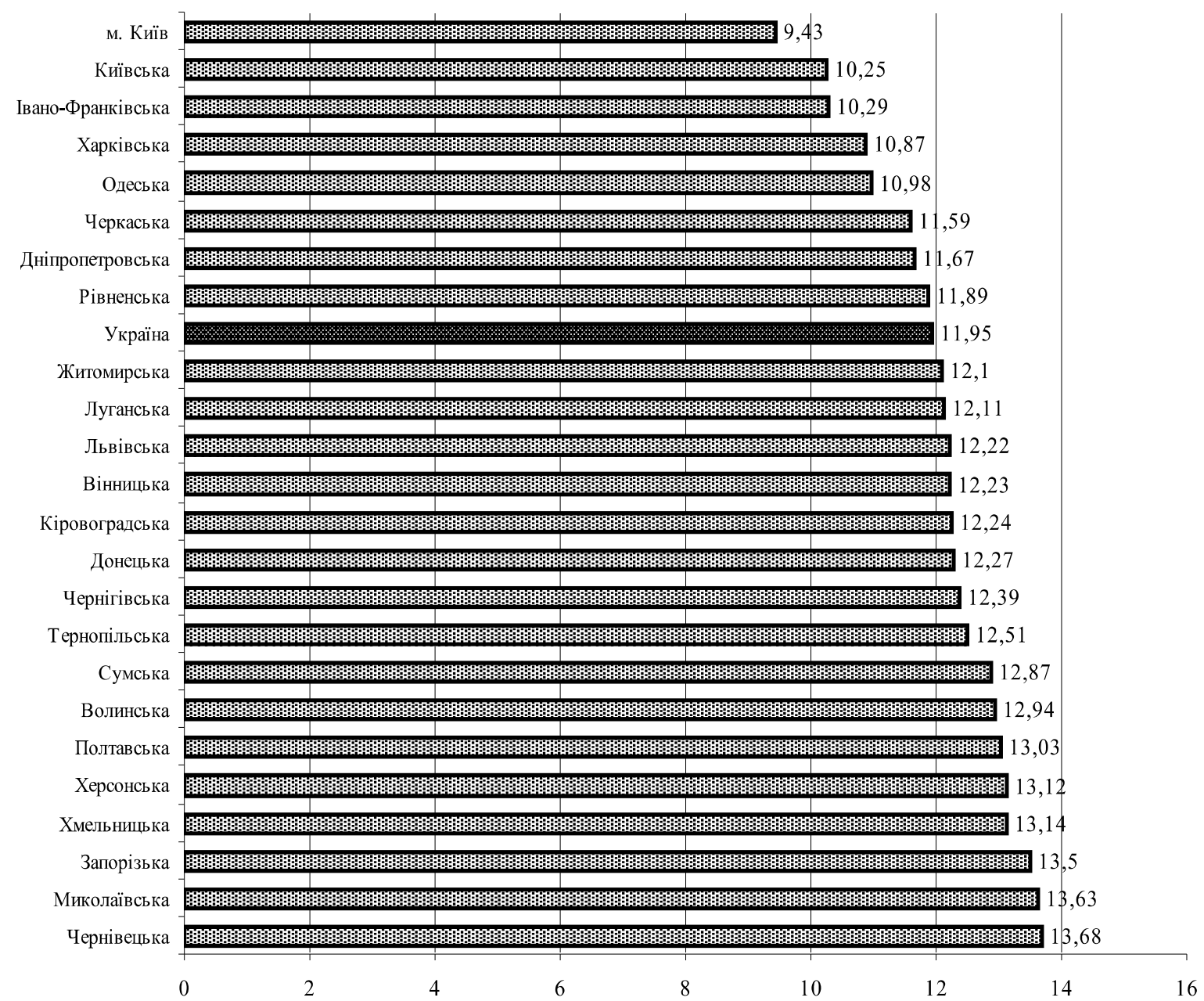

Рuc. 3. Співвідношення зареєстрованої кількості хвороб та інвалідів по регіонах у 2017 р. (кількість інвалідів на 1000 хвороб). 
відростка, ендокринні хвороби, розлади харчування та порушення обміну речовин. У середньому на 1000 зареєстрованих захворювань у дітей в 2013 р. припадало 11,0 інвалідів, у 2017 р. 11,9 з коливанням цього показника від 221,1 при природжених вадах розвитку, деформаціях та хромосомних аномаліях, 122,5 - при розладах психіки та поведінки, 81,8 - при новоутвореннях до 0,36 - при органах дихання, 1,28 - при захворюваннях шкіри і підшкірної клітковини, 13,9-8,6при хворобах кістково-м'язової системи та сполучної тканини, ока та його придаткового апарату.
У 2017 р., порівняно з 2013 р., значно збільшилася частота інвалідів серед дітей з природженими вадами розвитку, деформаціями і хромосомними аномаліями (221,3 і 212,8), розладами психіки і поведінки (122,5 і 93,1), новоутвореннями (81,8 і 71,3), хворобами нервової системи $(66,2$ і 62,0), ендокринними хворобами, розладами харчування та порушеннями обміну речовин $(27,5$ і 18,6$)$ відповідно, що може бути зумовлено як більш тяжким перебігом цих хвороб, так і більш повним використанням прав дітей на отримання інвалідності (рис. 4).

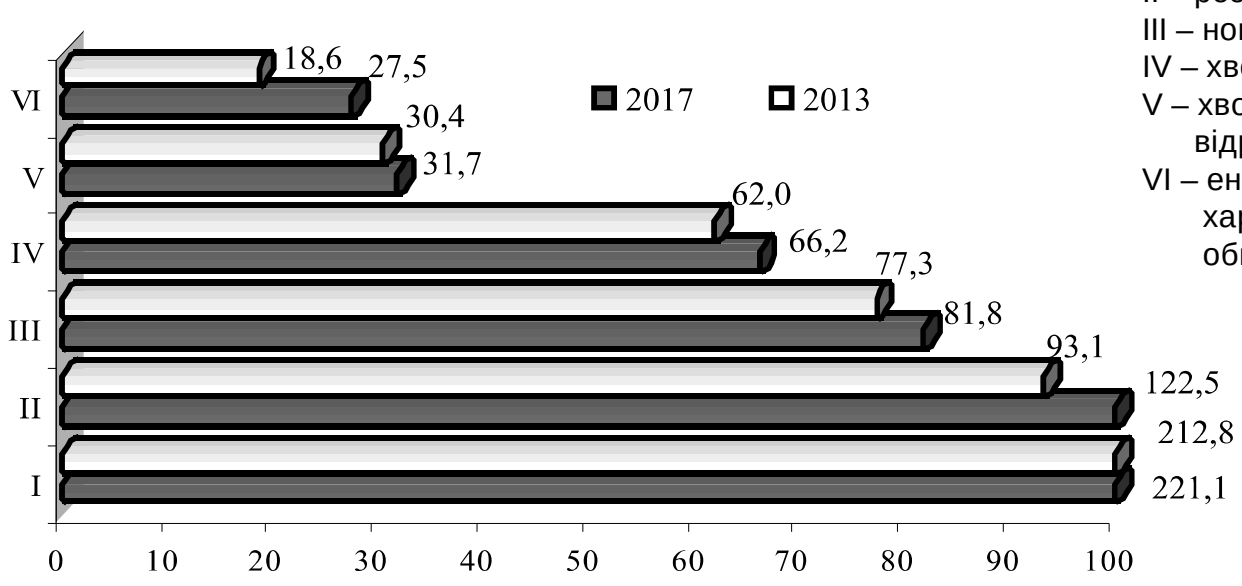
I - природжені вади розвитку, десормації

II - розлади психіки та поведінки

III - новоутворення

$\mathrm{V}$ - хвороби нервової системи

- хвороби вуха та соскоподібного відростка

VI - ендокринні хвороби, розлади харчування та порушення обміну речовин

Рuc. 4. Частка дітей-інвалідів у загальній кількості хворих дітей в Україні у 2013 і в 2017 р. (\%).

Аналіз показників дитячої інвалідності в області за окремими класами хвороб показав, що за період 2013-2017 рр. відбулося зменшення інвалідності за 9 класами хвороб і збільшення за 7 класами. Більш інтенсивні темпи зменшення характерні для інвалідності зумовленої хворобами органів травлення (темп зменшення 20,0 \%), хворобами ока та його придаткового апарату (17,9 \%), органів дихання (12,7\%), травмами, отруєннями та деякими іншими наслідками зовнішніх чинників $(11,1 \%)$. Зростання інвалідності спостерігається в основному у дітей з ендокринними хворобами, розладами харчування та порушеннями обміну речовин (темп приросту 19,9 \%), хворобами шкіри та підшкірної клітковини (11,1\%), розладами психіки і поведінки (7,5 \%), хворобами системи кровообігу (5,6 \%) (табл.).

При цьому динаміка первинної інвалідності дітей була менш вираженою - зросла лише інвалідність дітей, зумовлена ендокринними хворобами, розладами харчування та порушеннями обміну речовин і розладами психіки та поведінки, а зменшилася у дітей з природженими вадами розвитку, десормаціями та хромосомними аномаліями і травмами, отруєннями та деякими іншими наслідками зовнішніх чинників.
Разом із цим, структура причин дитячої інвалідності залишається незмінною. В цілому в Україні стабільно лідирують в структурі інвалідності у дітей природжені вади розвитку, десормації та хромосомні аномалії (30,4 \% у 2013 р. і 30,9 \% у 2017 р.), хвороби нервової системи (17,6 і 16,3 \%, в 2012 р. 26,6 \%), розлади психіки і поведінки (13,9 і 15,1 \%), ендокринні хвороби, розлади харчування та порушення обміну речовин (7,4 і 9,0 \%), хвороби вуха і соскоподібного відростка (6,8 і 6,4 \%) відповідно (рис. 5).

Як і в попередні роки, у 2017 р. спостерігається зростання інвалідності залежно від віку: 3 75,9 на 10 тис. дітей відповідного віку серед дітей 0-2 років до 167,6 серед дітей 3-6 років, 27505 серед дітей 7-14 років та до 291,7 серед дітей підліткового віку. Зростання інвалідності з віком притаманне зростанню її за усіма причинами. Більш інтенсивними темпами зростала інвалідність дітей з віком, зумовлена розладами психіки - 0,3 на 10 тис. відповідного населення у дітей віком до 3-х років та 20,1 у дітей віком 3-6 років, 44,4 - віком 7-14 років і 47,8 віком 15-17 років, хворобами кістково-м'язової системи - 0,7, 4,0, 11,4 і 20,4, хворобами органів дихання - 0,3, 1,3 4,6 і 7,1, хворобами ока та його придаткового апарату - 08, 3,1, 10,2 і 16,9 (рис. 6). 
Таблиця. Динаміка загальної та первинної інвалідності дітей за класами хвороб в Україні у 2013 та 2017 р. (на 10 тис. дітей віком до 18 років)

\begin{tabular}{|l|c|c|c|c|}
\hline \multicolumn{1}{|c|}{ Клас хвороб } & \multicolumn{2}{c|}{ Загальна інвалідність } & \multicolumn{2}{c|}{ Первинна інвалідність } \\
\cline { 2 - 4 } & 2013 & 2017 & 2013 & 2017 \\
\hline Деякі інфекційні та паразитарні хвороби & 4,3 & 4,1 & 0,5 & 0,3 \\
\hline Новоутворення & 7,1 & 7,3 & 1,1 & 1,1 \\
\hline $\begin{array}{l}\text { Хвороби крові, кровотворних органів та окремі порушення із } \\
\text { залученням імунного механізму }\end{array}$ & 2,1 & 2,0 & 0,2 & 0,2 \\
\hline $\begin{array}{l}\text { Ендокринні хвороби, розлади харчування та порушення обміну } \\
\text { речовин }\end{array}$ & 15,6 & 18,7 & 2,2 & 2,6 \\
\hline Хвороби нервової системи & & & \\
\hline Розлади психіки і поведінки & 37,1 & 34,0 & 3,1 & 2,4 \\
\hline Хвороби ока та його придаткового апарату & 29,2 & 31,4 & 3,5 & 4,1 \\
\hline Хвороби вуха та соскоподібного відростка & 9,5 & 7,8 & 08 & 08 \\
\hline Хвороби системи кровообігу & 14,3 & 13,3 & 1,1 & 1,0 \\
\hline Хвороби органів дихання & 1,8 & 1,9 & 0,3 & 0,3 \\
\hline Хвороби органів травлення & 4,4 & 3,4 & 0,4 & 0,4 \\
\hline Хвороби шкіри та підшкірної клітковини & 2,5 & 2,0 & 0,3 & 0,3 \\
\hline Хвороби кістково-м'язової системи та сполучної тканини & 9,5 & 8,9 & 1,4 & 1,4 \\
\hline Хвороби сечостатевої системи & 0,9 & 1,0 & 0,1 & 0,1 \\
\hline Природжені вади розвитку, десормації та хромосомні аномалії & 64,1 & 64,5 & 6,7 & 5,5 \\
\hline Травми, отруєння та деякі інші наслідки дії зовнішніх чинників & 4,5 & 4,0 & 0,6 & 0,5 \\
\hline Всього & 210,6 & 208,8 & 22,9 & 21,6 \\
\hline
\end{tabular}

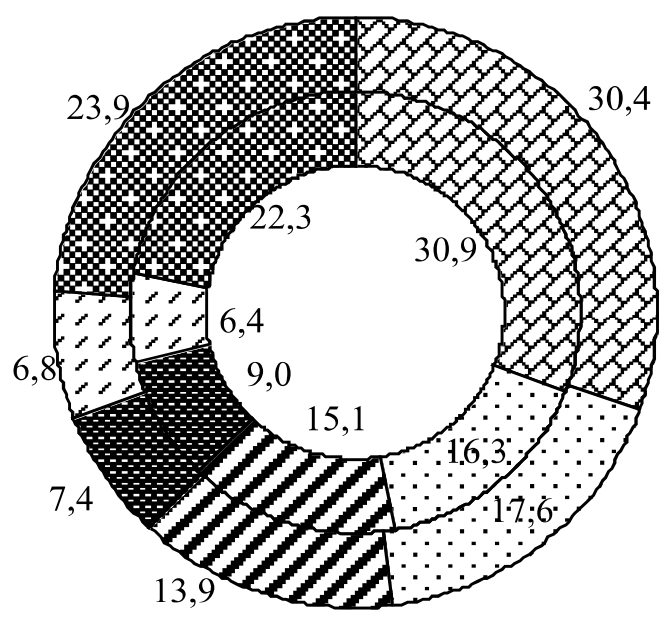

จ Уроджені аномалії, дефор мації та хромосомні порушення

$\square$ Хвороби нервової системи

Р Розлади психіки та поведінки

圆 Ендокринні хвороби

『 Хвороби вуха та соскоподібного відростка

由 Інші

Рuc. 5. Динаміка структури інвалідності дітей віком 0-17 років включно в Україні у 2013 і 2017 р. (\%).

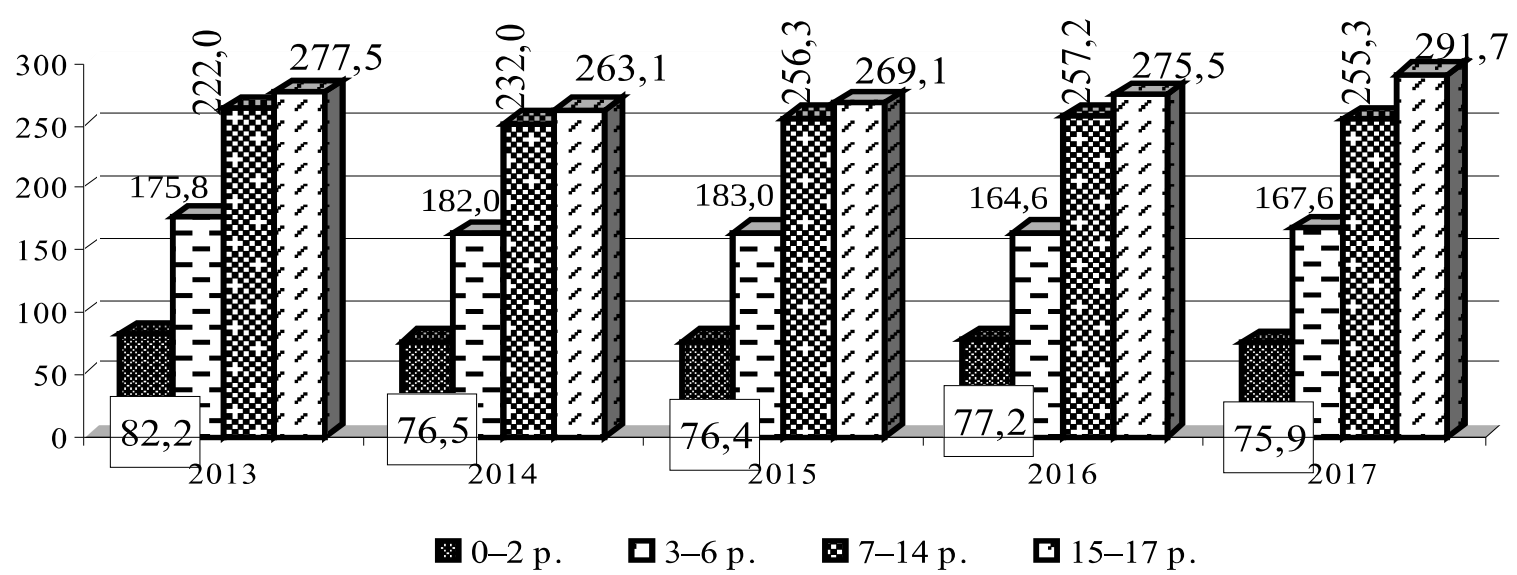

Рuc. 6. Динаміка інвалідності дітей окремих вікових груп в Україні у 2013-2017 рр. (на 10 тис. відповідного населення). 
На тлі спадної тенденції показника загальної інвалідності серед загальної популяції дітей за проаналізований період зменшилася інвалідність лише у вікових групах дітей 0-2 роки (82,2 на 10 тис. відповідного населення у 2013 р. і 75,9 у 2017 р.) та 3-6 років $(175,8$ і 167,0) і зросла інвалідність серед дітей віком 7-14 років із 222,0 до 255,3 та серед дітей підліткового віку з 277,5 до 291,7 відповідно.

\section{Висновки}

На тлі зниження загальної інвалідності у дітей підвищується поширеність інвалідності, зумовленої ендокринними хворобами, розладами харчування та порушеннями обміну речовин, хворобами шкіри та підшкірної клітковини, розладами психіки та поведінки, хворобами системи кровообігу. У структурі інвалідності у дітей та підлітків лідирують природжені вади розвитку, десрормації та хромосомні аномалії, хвороби нервової системи, розлади психіки і поведінки. У міру дорослішання дітей збільшується і сягає максимальних значень у віці 15-17 років загальна інвалідність. Регіональні особливості загальної і первинної інвалідності незначні, що свідчить про керованість показників дитячої інвалідності.

Перспективи подальших досліджень пов'язані 3 вивченням есрективності реабілітації дітейінвалідів.

\section{Список літератури}

1. Державна служба статистики України [Електронний ресурс]. - Режим доступу : http://www.ukrstat.gov.ua/operativ/ oper_new.html. - Назва з екрана.

2. Європейська база даних «Здоров'я для всіх» [Електронний ресурс]. - Режим доступу : http://www.euro.who.int/ hfadb?language=Russian. - Назва $з$ екрана.

3. Мировая статистика здравоохранения. 2012 год. - Женева : ВОЗ, 2013. - 176 с.

4. Основные показатели здоровья в Европейском регионе ВОЗ. 2013 г. - Копенгаген : ЕРБ ВОЗ, 2013. - 10 с.

5. Стан здоров'я дітей 0-17 років включно за 2015 рік (аналітично-статистичний довідник) / Центр медичної статистики МОЗ України. - К., 2016.

6. Яковлева Т. В. Государственная политика в области охраны здоровья детей: проблемы и задачи / Т. В. Яковлева, А. А. Баранов // Вопросы современной педиатрии. - 2009. - Т. 8, № 2. - С. 6-10.

\section{References}

1. Derzhavna sluzhba statystyky Ukrainy [State Statistics Service of Ukraine ]. - Retrieved from: http://www.ukrstat.gov.ua/ operativ/oper_new.html. [in Ukrainian]

2. Yevropeiska baza danykh "Zdorovia dlia vsikh" [European data base]. - Retrieved from: http://www.euro.who.int/ hfadb?language=Russian [in Ukrainian].

3. Mirovaya statistika zdravookhraneniya [World health statistics 2012]. Geneva: VOZ [in Russian].

4. Osnovni pokaznyky zdorovia v Evropeiskomu rehioni VOZ 2013 r. [Key health indicators in the WHO European Region 2013]. Copenhagen: ERB VOZ [in Ukrainian].

5. (2016). Stan zdorovia ditei 0-17 rokiv vkliuchno za 2015 rik (analitychno-statystychnyi dovidnyk) [The state of health of children 0-17 years inclusive for 2015 (analytical and statistical guide]. Tsentr medychnoi statystyky MOZ Ukrainy - Center of medical statistics of the Ministry of Health of Ukraine. Kyiv [in Ukrainian].

6. Yakovlieva, T.V., \& Baranov, A.A. (2009). Gosudarstvennaya politika v oblasti okhrany zdorovya detey: problemy i zadachi [State policy in the field of children's health: problems and tasks]. Voprosy sovremennoy pediatrii - Issues of Modern Pediatrics, 8 (2), 6-10.

\section{ХАРАКТЕРИСТИКА ИНВАЛИДНОСТИ ДЕТСКОГО НАСЕЛЕНИЯ УКРАИНЫ}

\section{Г.А. Слабкий', А.Н. Дзюба 2,3, Е.А. Дудина², Ю.Ю. Габорец²}

1ГВУЗ «Ужгородский национальный университет», г. Ужгород, Украина

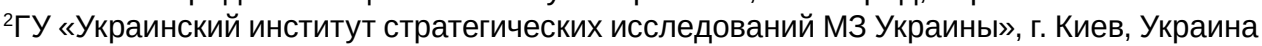

${ }^{3}$ Колледж образования и терапии имени проф. Казимира Милановского, г. Познань, Польша

Цель: изучить и проанализировать показатели инвалидности детского населения в Украине.

Материалы и методы. Материалами исследования служили данные государственной статистической отчетности за период 2013-2017г. В ходе исследования использовано статистический метод.

Результаты. При снижении общего показателя инвалидности детей повышается показатель распространенности среди них инвалидности, которая обусловлена эндокринными болезнями, нарушениями питания и нарушениями обмена веществ; болезнями кожи и подкожной клетчатки; нарушениями психики и поведения; болезнями системы кровообращения. В структуре инвалидности у детей лидируют врожденные пороки развития, десормации и хромосомные аномалии, болезни нервной системы, нарушения психики и поведения. 
Выводы. Високие показатели общей и первичной инвалидности детей требуют принятия государственной программы их реабилитации.

КЛЮЧЕВЫЕ СЛОВА: дети; инвалидность; общая; первичная; показатели; структура.

\section{CHARACTERISTICS OF DISABILITY AMONG INFANT POPULATION IN UKRAINE}

G.O. Slabkiy' , O.M. Dzyuba',3 O.A. Dudina'2, Yu.Yu. Gaborets ${ }^{2}$

${ }^{1}$ Uzhhorod National University, Uzhhorod, Ukraine

2Ukrainian Institute of Strategic Research of Ministry of Health of Ukraine, Kiyv, Ukraine

${ }^{3}$ College of Education and Therapy named after prof. Casimir Milanovsky, Poznan, Poland

Purpose: to study and analyze the indices of disability among infant population in Ukraine.

Materials and Methods. The data of State statistical reporting for the years 2013-2017 were used as materials of research. Statistical method was applied in the course of research.

Results. The total index of infants' disability is decreasing alongside with increasing index of the prevalence of disability among infants that is caused by endocrine diseases, nutrition and metabolism disorders, diseases of the skin and fatty tissue, mental and behavioral disorders, diseases of blood circulation. The leading positions in the structure of infants' disability belong to congenital defects of development, deformations and chromosome anomalies, diseases of the nervous system, mental and behavioral disorders.

Conclusions. High indices of total and primary disability of infants require the development of State program for their rehabilitation.

KEY WORDS: infants; disability; total; primary; indices; structure.

Рукопис надійшов до редакції 24.05.2018 р.

\section{Відомості про авторів:}

Слабкий Геннадій Олексійович - доктор медичних наук, професор, завідувач кафедри громадського здоров'я факультету післядипломної освіти та доуніверситетської підготовки дВНЗ «Ужгородський національний університет».

Дзюба Олександр Миколайович - доктор медичних наук, профресор, заступник директора з наукової роботи ДУ «Український інститут стратегічних досліджень Міністерства охорони здоров'я України».

Дудіна Олена Олександрівна - кандидат медичних наук, старший науковий співробітник, завідувач відділення охорони здоров'я матері і дитини ДУ «Український інститут стратегічних досліджень Міністерства охорони здоров'я України».

Габорець Юрій Юрійович - кандидат медичних наук, пошукач ДУ «Український інститут стратегічних досліджень Міністерства охорони здоров'я України». 